Jurnal Keperawatan Silampari

Volume 5, Nomor 1, Desember 2021

e-ISSN: 2581-1975

p-ISSN: 2597-7482

DOI: https://doi.org/10.31539/jks.v5i1.1971

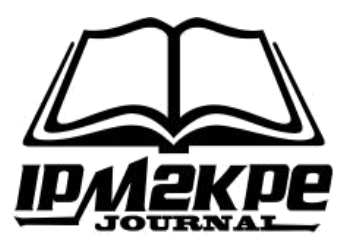

\title{
KEPUASAN PERNIKAHAN BERHUBUNGAN DENGAN DEPRESI PASCA MELAHIRKAN
}

\author{
Irma Nurbaeti ${ }^{1}$, Iklil Farida ${ }^{2}$ \\ Universitas Islam Negeri Syarif Hidayatullah Jakarta ${ }^{1,2}$ \\ irma.nurbaeti@uinjkt.ac.id ${ }^{1}$
}

\begin{abstract}
ABSTRAK
Penelitian ini bertujuan untuk mengetahui hubungan kepuasan pernikahan dengan depresi pasca melahirkan pada ibu postpartum di kota Tangerang Selatan. Jenis penelitian yang digunakan adalah penelitian kuantitatif dengan pendekatan cross-sectional. Hasil penelitian didapatkan sebanyak 60 responden $(20,55 \%)$ mengalami depresi pasca melahirkan dengan skor EPDS lebih dari 13 dan 15 responden $(5,16 \%)$ tidak puas dengan pernikahannya. Simpulan, terdapat hubungan antara kepuasan pernikahan dengan depresi pasca melahirkan dengan nilai $\mathrm{p}$ 0,018. Ibu yang merasa tidak puas dengan pernikahannya cenderung mengalami depresi postpartum.
\end{abstract}

Kata Kunci: Depresi Postpartum, Kepuasan Pernikahan, Maternal, Perawat

\begin{abstract}
This study aims to determine the relationship between marital satisfaction and postpartum depression in postpartum mothers in South Tangerang. The type of research used is quantitative research with a cross-sectional approach. The results showed that 60 respondents $(20.55 \%)$ experienced postpartum depression with an EPDS score of more than 13, and 15 respondents (5.16\%) were dissatisfied with their marriage. In conclusion, there is a relationship between marital satisfaction and postpartum depression with a pvalue of 0.018. Mothers who are dissatisfied with their marriages tend to experience postpartum depression.
\end{abstract}

Keywords: Postpartum Depression, Marital Satisfaction, Maternal, Nurse

\section{PENDAHULUAN}

Depresi pasca melahirkan merupakan gangguan depresi mayor yang terjadi paling cepat pada empat minggu setelah persalinan sampai dengan satu tahun pasca melahirkan. Depresi pasca melahirkan dapat menimbulkan dampak pada hubungan ibu dan bayi seperti ketidakefektifan menyusui serta dampak jangka panjang yang berpengaruh pada pasangan dan keluarga. Kejadian depresi pasca melahirkan dapat didahului dengan kejadian postpartum blues. Perasaan sedih yang berlanjut disertai dengan kecemasan dapat berubah menjadi kondisi depresi postpartum dan pada beberapa kondisi yang parah dapat menjadi psikosis postpartum (Matinnia et al., 2018).

Nurbaeti et al., (2019) melakukan penelitian pada sebagian ibu usia dewasa di Indonesia. Hasil penelitian menunjukkan 26,15\% partisipan terindikasi mengalami depresi pasca melahirkan pada bulan ketiga setelah kelahiran dengan skor EPDS lebih dari 13. Beberapa kasus diseluruh dunia disebutkan bahwa depresi pasca melahirkan yang tidak 
tertangani dengan baik dapat bertambah parah dan menjadi penyebab terjadinya bunuh diri. Ay et al., (2018) menyebutkan riwayat depresi pada ibu dan keluarga, kurangnya edukasi, kehamilan tidak direncanakan, status pekerjaan, memiliki banyak anak, multipara, dan hubungan negatif dengan pasangan merupakan faktor yang mempengaruhi depresi.

Hubungan negatif dengan pasangan dapat menyebabkan buruknya kualitas pernikahan dan ketidakpuasan pernikahan. Hal tersebut dapat berdampak pada dukungan yang diberikan oleh pasangan terhadap ibu. Pada masa postpartum sebagian ibu mungkin membutuhkan dukungan dari pasangannya. Sebagian ibu yang memiliki dukungan dan kepuasan pernikahan yang buruk cenderung lebih mudah mengalami depresi dibandingkan dengan ibu yang memiliki kepuasan dalam pernikahannya. Sementara Park (2018) menyatakan pada sebagian ibu di Korea menunjukkan tingginya konflik perkawinan menyebabkan kurangnya dukungan dari pasangan sehingga timbul ketidakmampuan ibu untuk mengatasi stress. Sebaliknya, mereka yang mempunyai hubungan positif dengan pasangannya memberikan pengaruh yang signifikan pada kemampuan ibu untuk mengatasi stress.

Penelitian mengenai depresi pasca melahirkan dengan kepuasan pernikahan di Indonesia umumnya dan di Tangerang Selatan belum banyak diteliti. Selain itu, skrinning depresi pasca melahirkan belum banyak dilakukan pada beberapa pelayanan kesehatan. Menimbang adanya dampak dari depresi pasca melahirkan dan kepuasan pernikahan, maka penelitian hubungan kepuasan pernikahan dengan depresi pasca melahirkan penting dilakukan. Tujuan penelitian adalah mengidentifikasi hubungan antara kepuasan pernikahan dengan depresi pasca melahirkan pada ibu postpartum.

\section{METODE PENELITIAN}

Desain penelitian yang digunakan adalah penelitian kuantitatif analitik dengan pendekatan cross-sectional. Penelitian dilakukan di Kota Tangerang Selatan pada bulan Maret - Juli tahun 2016. Populasi adalah seluruh ibu masa postpartum 1 bulan dengan kriteria sampel ibu dalam kondisi sehat, bayi lahir hidup, kehamilan aterm dan bersedia berpartisipasi dalam penelitian. Kriteria ekslusi adalah ibu memiliki riyawat gangguan jiwa, ibu dan bayi sedang menjalani perawatan di rumah sakit atau pelayanan kesehatan

\section{Instrumen Penelitian}

Karakteristik responden yang digunakan adalah informasi mengenai ibu dan bayi. Informasi mengenai ibu berupa usia, pendidikan, pekerjaan, paritas, dan jenis persalinan. Informasi bayi adalah jenis kelamin bayi dan berat bayi pada saat lahir.

Instrumen yang digunakan untuk mengukur dapresi pasca melahirkan yaitu The Edinburg Postnatal Depression Scale (EPDS) versi Bahasa Indonesia. EPDS merupakan kuesioner yang dikembangkan oleh Cox et al pada tahun 1987 dan digunakan untuk mengukur perubahan mood pada 7 hari terakhir pasca melahirkan. EPDS memiliki 10 pertanyaan dan 4 pilihan jawaban dengan skor 0-3.

Instrumen yang digunakan untuk mengukur kepuasan pernikahan adalah The Dyadic Adjustment Scale (DAS) yang dikembangkan oleh Spanier (1976). DAS merupakan instrumen yang telah teruji validitas dan reliabilitasnya. Uji reliabilitas pada instrumen DAS menggunakan Cronbach'a Alpha diketahui memiliki nilai 0,96. Hasil tersebut menunjukkan bahwa skala total dan komponen pada DAS memiliki keandalan yang cukup tinggi. DAS memiliki total skor 151. Skor tertinggi diatas 100 mengindikasikan hubungan dengan kepuasan pernikahan yang baik, sedangkan skor dibawah 100 mengindikasikan adanya disterss dan ketidakpuasan pernikahan. 


\section{Pengumpulan Data}

Persiapan penelitian dilakukan dengan mengajukan persetujuan etik, ijin tempat penelitian, memperbanyak kuesioner dan melatih enumerator. Peneliti dibantu oleh dua orang asisten peneliti dan delapan orang pengumpul data (enumerator) di masing-masing kecamatan di wilayah Kota Tangerang Selatan. Pelatihan enumerator dilakukan selama satu hari dengan tujuan untuk mendapatkan kesamaan persepsi tentang tujuan penelitian dan pengumpulan data.

Pengumpulan data dilaksanakan setelah mendapatkan persetujuan etik dan mendapatkan ijin penelitian dari Kepala dinas kesehatan Kota Tangerang Selatan. Peneliti dan/atau enumerator akan mengidentifikasi calon responden. Responden yang memenuhi syarat diminta berpartisipasi dalam penelitian. Peneliti dan/atau enumerator akan menjelaskan maksud dan tujuan penelitian, manfaat penelitian dan cara mengisi kuesioner. Jika responden setuju untuk berpartisipasi, responden diminta untuk menandatangani informed consent. Pengumpulan data dilakukan melalui kunjungan rumah. Pengumpulan data dengan teknik wawancara terbimbing dengan berpedoman pada kuesioner selama kurang lebih 15 menit. Responden tidak didampingi oleh suami atau keluarga saat pengisian kuesioner. Persetujuan etik telah diberikan oleh Komisi Etik Penelitian Kesehatan Burapha University Thailand.

\section{Analisis Data}

Analisis univariat dilakukan untuk mendeskripsikan distribusi prosentase masingmasing variable yaitu karakteristik responden, kepuasan pernikahan dan depresi pasca melahirkan. Analisis bivariat yang digunakan adalah uji Chi Square $\left(x^{2}\right)$ karena variabel yang diujikan berbentuk kategorik dengan kategorik dengan tingkat kepercayaan $95 \%$ ( $\alpha$ $5 \%$ ).

\section{HASIL PENELITIAN}

Tabel. 1

Karakteristik Responden (N=292)

\begin{tabular}{ccc}
\hline Karakteristik Ibu & $\mathrm{n}$ & $\%$ \\
\hline Usia (tahun) & & \\
$-\quad<20$ & 7 & 2,40 \\
$-\quad 20-35$ & 246 & 84,25 \\
$-\quad>35$ & & 13,35 \\
\hline Tingkat Pendidikan & 22 & 7,53 \\
$-\quad$ SD atau setara & 51 & 17,47 \\
$-\quad$ SMP atau setara & 159 & 54,45 \\
$-\quad$ SMA atau setara & 60 & 20,55 \\
$-\quad$ Perguruan Tinggi & & \\
Pekerjaan & 234 & 80,14 \\
$-\quad$ IRT & 58 & 19,86 \\
$-\quad$ Bekerja & 88 & 30,14 \\
\hline Jumlah anak & 137 & 46,92 \\
$-\quad 1$ & 67 & 22,94 \\
$-\quad 2$ & & \\
$-\quad 3$ dan lebih & 224 & 76,71 \\
\hline Jenis persalinan & 18 & 6,16 \\
$-\quad$ Normal/pervaginam & 50 & 17,12 \\
$-\quad$ Vakum/forcep & & \\
$-\quad$ Seksio sesaria & & \\
\hline
\end{tabular}




\begin{tabular}{rcc}
\hline Karakteristik Bayi & & \\
\hline Jenis kelamin anak & & \\
$\quad \quad$ Laki-laki & 132 & 45,21 \\
$-\quad$ Perempuan & 160 & 54,79 \\
\hline Berat badan bayi lahir (gram) & 7 & \\
$\quad \quad$ Kurang 2500 & 285 & 2,40 \\
$-\quad$ 2500 dan lebih & & 97,60 \\
\hline
\end{tabular}

Berdasarkan karakteristik responden didapatkan bahwa sebagian besar responden berada pada rentang usia sehat secara reproduksi yaitu rentang usia 20 - 35 tahun sebanyak $84,25 \%$ sedangkan usia resiko tinggi sebanyak $15,75 \%$. Lebih dari separuh responden memiliki tingkat pendidikan SMA atau setara yaitu sebanyak 54,45\%. Pekerjaan responden Sebagian besar $(80,14)$ adalah sebagai ibu rumah tangga, dan hampir separuh memiliki 2 anak $(46,92 \%)$ dengan Sebagian besar responden melahirkan secara normal/spontan atau pervaginaam yaitu sebanyak $76,71 \%$.

Karakeristik bayi terbagi dua yaitu jenis kelamin dan berat badan bayi saat lahir didapatkan data bayi yang lahir sebagai anak perempuan lebih banyak dibandingkan lakilaki yaitu 54,79\% dengan rata-rata berat bayi dalam normal yaitu lebih atau sama dengan 2500 gram sebanyak 97,60\% sedangkan sebagian kecil bayi ada yang dilahirkan kurang dari 2500 gram sebanyak $2,40 \%$.

\section{Gambaran Depresi Pasca melahirkan}

Tabel. 2

Distribusi Persentase Depresi Pasca Melahirkan

$(\mathrm{N}=292)$

\begin{tabular}{ccc}
\hline Depresi pasca melahirkan & $\mathrm{n}$ & Persentase (\%) \\
\hline Depresi & 60 & 20,55 \\
Tidak depresi & 232 & 79,45 \\
\hline
\end{tabular}

Hasil penelitian menunjukkan bahwa sebanyak 60 responden $(20,55 \%)$ menunjukkan gejala depresi pasca melahirkan dengan skor EPDS sebesar 13 atau lebih sebagai cut-off.

\section{Hubungan Kepuasan Pernikahan dengan Depresi Pasca Melahirkan}

Tabel. 3

Hubungan Kepuasan Pernikahan dengan Depresi Pasca Melahirkan (N=292)

\begin{tabular}{|c|c|c|c|c|c|c|c|}
\hline \multirow{3}{*}{$\begin{array}{l}\text { Kepuasan } \\
\text { Pernikahan }\end{array}$} & \multicolumn{4}{|c|}{ Depresi Postpartum } & \multirow{2}{*}{\multicolumn{2}{|c|}{ Jumlah }} & \multirow[t]{3}{*}{ Nilai-p } \\
\hline & \multicolumn{2}{|c|}{$\mathrm{Ya}$} & \multicolumn{2}{|c|}{ Tidak } & & & \\
\hline & $\mathrm{n}$ & $\%$ & $\mathrm{n}$ & $\%$ & $\mathrm{n}$ & $\%$ & \\
\hline Tidak puas & 7 & 46,67 & 8 & 53,33 & 15 & 100 & \\
\hline Puas & 53 & 19,13 & 224 & 80,87 & 277 & 100 & 0,018 \\
\hline Total & 60 & 20,55 & 232 & 79,45 & 292 & 100 & \\
\hline
\end{tabular}

Berdasarkan tabel 3 didapatkan bahwa sebanyak 15 responden $(5,14 \%)$ teridentifikasi merasa tidak puas terhadap pernikahannya dengan skor nilai DAS 100 atau kurang. Tujuh dari $15(46,67 \%)$ responden yang tidak puas dengan pernikahannya mengalami depresi pasca melahirkan. Sedangkan sebanyak 277 responden $(19,13 \%)$ yang memiliki skor 
kepuasan yang tinggi terhadap pernikahannya sebanyak 53 orang $(19,13 \%)$ mengalami depresi pasca melahirkan.

Untuk menguji hubungan kepuasan pernikahan dilakukan uji Chi square. Hasil uji statistik menunjukkan nilai-p $=0,018$ atau nilai-p $<0.05$, sehingga dapat disimpulkan ada hubungan antara kepuasan pernikahan dengan depresi pasca melahirkan pada ibu postpartum. Selanjutnya dilakukan analisis odd ratio (OR).

Tabel. 4

Odd Ratio (OR)

\begin{tabular}{cccc}
\hline \multirow{2}{*}{ Estimasi } & \multirow{2}{*}{ Asymptotic significance } & \multicolumn{2}{c}{$95 \%$ Convidence Interval $($ CI) } \\
& Lower Bound & UPPER bound \\
\hline 3,67 & 0,015 & 1,28 & 10,65 \\
\hline
\end{tabular}

Berdasarkan tabel 4 didapatkan data ibu dengan kepuasan pernikahan yang rendah sebanyak 3,67 kali beresiko mengalami depresi pasca melahirkan. Setidaknya faktor ketidakpuasan terhadap pernikahan memiliki peluang 1,28 sampai 10,65 kali terhadap resiko kejadian depresi pasca melahirkan.

\section{PEMBAHASAN}

Hasil penelitian menunjukkan bahwa sebagian besar responden mengalami depresi pasca melahirkan. Sejalan dengan penelitian Nurbaeti et al., (2019) di Jakarta Selatan dengan angka depresi pasca melahirkan 19.88\%. WHO (2019) juga menyebutkan bahwa prevalensi depresi pasca melahirkan di negara berkembang adalah sekitar 19,8\% dan angka ini lebih tinggi dibandingkan dengan prevalensi di negara maju.

Saat ini pelayanan Kesehatan ibu pada umumnya belum banyak yang menjalankan program skrining depresi pasca melahirkan. Skrining depresi postpartum ini memungkinkan untuk mengidentifikasi gejala dari depresi pasca melahirkan. Depresi pasca melahirkan yang dapat diidentifikasi dari awal dapat menurunkan resiko yang lebih parah. Keluarga terutama pasangan perlu diedukasi mengenai perubahan psikologis setelah melahirkan dan gejala yang mungkin muncul. Keluarga juga perlu memahami ketika ibu mulai terlihat tidak seperti biasanya.

Dari hasil penelitian ini didapatkan bahwa tingkat depresi pasca melahirkan di terbilang cukup tinggi. Angka tersebut dapat meningkat seiring dengan meningkatnya angka kelahiran. Hal ini perlu diwaspadai mengingat dampak dari depresi pasca melahirkan yang tidak hanya terjadi pada ibu tetapi dapat terjadi pada bayi dan juga pasangannya. Ibu yang mengalami depresi pasca melahirkan akan kesulitan untuk menjalani aktifitas seharihari dan merasa mengalami penderitaan yang berat.

\section{Gambaran Kepuasan Pernikahan}

Kepuasan pernikahan diketahui sebagai faktor prediktor terhadap kejadian depresi pasca melahirkan. Hasil penelitian menunjukkan sebanyak 5,14\% responden tidak puas dengan pernikahannya. Yulianty (2018) melakukan penelitian kualitatif pada 2 ibu yang mengalami depresi pasca melahirkan. Kedua responden menyebutkan bahwa masalah perkawinan merupakan salah satu faktor yang mempengaruhi kondisinya saat ini. Ibu yang mengalami depresi pasca melahirkan merasa bahwa suami kurang memberikan dukungan dan juga kurang memberikan perhatiannya. Kurangnya perhatian yang diberikan suami kepada ibu serta kurangnya komunikasi dapat membuat ibu merasa sendiri dalam 
menghadapi masalahnya. Hal tersebut membuat ibu merasa tidak puas terhadap perilaku suaminya dan berdampak pada ketidakpuasannya dalam pernikahan.

Ibu yang mengalami depresi selama kehamilan maupun pasca persalinan dapat membaik jika mendapatkan kepuasan dalam pernikahan. Kepuasan pernikahan yang dirasakan ibu dipengaruhi oleh adanya dukungan dari suami. Ketika ibu mendapatkan dukungan dari suami serta aspek kepuasan pernikahannya terpenuhi, maka hal tersebut dapat mempengaruhi ibu dalam mengatasi stressor yang ada. Seperti yang sudah diketahui sebelumnya, ibu postpartum kemungkinan mengalami banyak stressor pasca persalinanya seiring dengan perubahan yang dialaminya. Ibu memerlukan dukungan dan kerjasama yang baik dari suami untuk mengatasi masalahnya dengan baik.

\section{Hubungan antara Kepuasan Pernikahan dengan Depresi Pasca Melahirkan}

Hasil analisis menunjukkan adanya hubungan yang bermakna antara kepuasan pernikahan dengan depresi pasca melahirkan. Hasil penelitian ini sejalan dengan penelitian dari Chi et al., (2016) yang menyebutkan bahwa kualitas dan kepuasan terhadap pasangannya memiliki hubungan yang signifikan terhadap tingkat depresi pasca melahirkan. Hal ini dikarenakan dukungan yang diberikan pasangan berpengaruh terhadap kepuasan yang dirasakan ibu. Ibu lebih nyaman dan dapat mengatasi stressnya dengan baik apabila mendapatkan dukungan yang optimal dari pasangannya. Apabila dukungan yang diberikan tidak memadai maka menjadi pemicu timbulnya stress dan ketakutan serta rasa tidak berdaya pada ibu setelah melahirkan. Dari timbulnya stress tersebut dapat meningkatkan resiko depresi. Ibu merasakan kepuasan apabila pasangan dapat membantunya untuk berbagi peran dalam mengasuh bayi serta memberikan perhatiannya.

Kepuasan pernikahan yang dirasakan ibu sering berkaitan dengan dukungan yang diberikan suami setelah melahirkan. Penelitian dari Putriarsih et al., (2017) menunjukkan bahwa dukungan suami memiliki hubungan tidak langsung pada kejadian depresi pasca melahirkan melalui faktor kepercayaan diri dan kehamilan. Dengan dukungan tersebut ibu akan merasakan kepuasan pernikahan yang baik sehingga meningkatkan rasa percaya diri ibu dan dapat menjalani masa nifasnya dengan rasa nyaman dan tenang. Sebaliknya, suami dengan dukungan yang rendah akan mengakibatkan buruknya kualitas serta kepuasan pernikahan karena ibu merasa tidak nyaman dalam menjalani masa nifas sehingga ibu merasa seperti menghadapi masalahnya sendirian.

Hasil penelitian ini didapatkan angka depresi pasca melahirkan di kota Tangerang Selatan cukup tinggi dan angka kepuasan pernikahan yang juga cukup tinggi. Dari 60 responden yang terdeteksi mengalami depresi pasca melahirkan, hanya 7 diantaranya yang mengalami ketidapuasan pernikahan. Hal ini berarti terdapat 53 responden yang mengalami depresi pasca melahirkan, tetapi juga merasakan kepuasan pernikahan yang baik. Sebagian responden dengan kepuasan pernikahan yang baik ini dicurigai mengalami depresi dengan dipengaruhi faktor lain seperti usia, pekerjaan, pendidikan, paritas, persalinan, dan komplikasi persalinan.

Hasil penelitian ini diketahui bahwa ibu dengan kepuasan pernikahan yang rendah 3,67 kali beresiko mengalami depresi pasca melahirkan. Kepuasan pernikahan beresiko 1,28 sampai 10,65 kali terhadap kejadian depresi pasca melahirkan. Hal ini berarti semakin rendah kepuasan pernikahan maka semakin tinggi pula resiko ibu mengalami depresi pasca melahirkan. Sebaliknya, semakin tinggi kepuasan pernikahan maka resiko ibu untuk mengalami depresi akan semakin rendah. Sejalan dengan penelitian Nurbaeti et al., (2019) yang menyebutkan ibu dengan kepuasan pernikahan yang rendah lebih rentan mengalami depresi pasca melahirkan dibandingkan ibu dengan kepuasan pernikahan yang tinggi. 


\section{SIMPULAN}

terdapat hubungan antara kepuasan pernikahan dengan depresi pasca melahirkan pada ibu postpartum. Kepuasan pernikahan berkontribusi sebanyak 3,67 kali terhadap resiko ibu mengalami depresi pasca melahirkan.

\section{SARAN}

Disarankan untuk penelitian yang akan datang melakukan penelitian dengan desain longitudinal untuk meneliti kepuasan pernikahan terhadap depresi pasca melahirkan pada tahun pertama setelah melahirkan dan efek kepuasan pernikahan dengan depresi terhadap pola pengasuhan anak. Disarankan juga pada fasilitas Kesehatan Ibu dan Anak untuk melakukan deteksi dini depresi postpartum pada ibu postpartum.

\section{DAFTAR PUSTAKA}

Ay, F., Tektaş, E., Mak, A., \& Aktay, N. (2018). Postpartum Depression and the Factors Affecting It: 2000-2017 Study Results. Journal of Psychiatric Nursing, 9(3), 147152. https://doi.org/10.14744/phd.2018.31549

Chi, X., Zhang, P., Wu, H., \& Wang, J. (2016). Screening for Postpartum Depression and Associated Factors among Women in China: A Cross-Sectional Study. Frontiers in Psychology, 7(NOV). https://doi.org/10.3389/fpsyg.2016.01668

Matinnia, N., Ghaleiha, A., Jahangard, L., Ghaleiha, A., \& Farahmand, E. (2018). Psychological Risk Factors for Postnatal Depression: A Prospective Study of Iranian Low Income Primigravidae at Health Care Centres. Pertanika Journal of Social Sciences Humanities, 26(4), 2555-2569. http://www.pertanika.upm.edu.my/pjssh/browse/archives?article=JSSH-S0900-2017

Nurbaeti, I., Deoisres, W., \& Hengudomsub, P. (2019). Association Between Psychosocial Factors and Postpartum Depression in South Jakarta, Indonesia. Sexual and Reproductive Healthcare, 20, 72-76. https://doi.org/10.1016/j.srhc.2019.02.004

Park, K. T. (2018). Is the Moderating Effect of Social Support on New Korean Mothers' Psychological Distress Contingent on Levels of Marital Quality? Asia-Pacific Journal of Public Health, 30(2), 167-177. https://doi.org/10.1177/1010539517753735

Putriarsih, R., Budihastuti, U. R., \& Murti, B. (2017). Prevalence and Determinants of Postpartum Depression in Sukoharjo District, Central Java. Journal of Maternal and Child Health, 03(01), 395-408. https://doi.org/10.26911/thejmch.2017.03.01.02

WHO. (2019). Depression. https://www.who.int/en/news-room/factsheets/detail/depression

Yulianty, N. (2018). Kepuasan Perkawinan pada Ibu yang Mengalami Depresi Pasca Persalinan di Komunitas Motherhope Indonesia. Jurnal Ilmiah Penelitian Psikologi, 4(2), 87-94. https://doi.org/https://doi.org/10.22236/JIPP-50 